\title{
レオロジー特性を考慮した底泥の流動モデル \\ Hydraulic Model of Mud-Flow Considering \\ Rheological Properties
}

神田 徹* ・笹 真**

By Tohru KANDA, Makoto SASA

\begin{abstract}
As a result of measuring the rheological properties of mud using a rotational visco-meter, the mud can be considered as structural viscosity fluid. Te formulate a rheological equation of mud based on these properties. A hydraulic model of mud-flow under the flowing water is constructed by introducing the rheological equation. Computation using this hydraulic model can replicates the features of the velocity distribution of mud-flow which are recognized in hydraulic experiments.
\end{abstract}

Keywords:mud, non-Newtonian fluid, rheological model

\section{1. まえがき}

河口部や浅い湾などでは，堆積している底泥が水の流れや波により巻き上げられ，また流送されることに よって水域の污濁や富栄養化, シルテーションなどの問題が生じている.これらの問題の解決のためには, 巻き上げ・輸送・沈降といった底泥の移動機構の解明が必要であるが, そのためにはまず底泥の物性を把握 し，さらに，その物性が底泥の流動現象にどのように影響するかを明らかにしなければならない，底泥は， シルトや粘土といった微細粒子が主成分であること, また含水比が極めて高いという特徴から, 粘土粒子の 高濃度懸濁液であると考ることができる。このような微細粒子の㦟濁液では, 粒子接点に働く物理化学的力 の影響が大きく，複数の粒子が集まって集合体を形成する．この集合体が流動ともに破壊・再集合するので, これら懸濁液の物性値は, 含水比だけでなく, 液体の流動状態によっても変化することが知られている.こ れが底泥の流動現象を複雑にしている原因の一つである. 本研究では, 底泥がずり速度とともに粘度の変化 する構造粘性流体であるとして流動曲線の定式化を行い, これを用いた底泥の流動モデルを作成した. また， 底泥材料としてカオリナイトを用いて一方向流れ場における流送実験を行い, 底泥の流速分布および含水比 分布等を測定するとともに，流動モテルによる数值シミュレーション結果と比較検討した.

\begin{tabular}{|c|c|c|}
\hline * & 正会員 & $\begin{array}{l}\text { 工博 神戸大学教授 工学部建設学科 } \\
\text { ( } \text { (657 神戸市灘区六甲台町 1-1） }\end{array}$ \\
\hline$* *$ & 学生会員 & 神戸大学大学院工学研究科 \\
\hline
\end{tabular}




\section{2. 流動曲線}

\section{1 Ostwald 曲線}

一般に高分子濃厚溶液やグリースあるいは底泥などの多くの懸濁液では，せん断応力とずり速度の関係が 非線形である．これら非線形の現象を表す式として，(1) 式が与えられている.

$$
\begin{aligned}
& \tau-\tau_{\mathrm{y}}=\mu_{\mathrm{app}} \mathrm{D}^{\mathrm{n}} \\
& \tau_{\mathrm{y}}=0, \mathrm{n}=1: \text { 二ュートン流体, } \tau_{\mathrm{y}}=0, \mathrm{n}<1: \text { 擬塑性流体, } \\
& \tau_{\mathrm{y}}=0, \mathrm{n}>1: \text { ダイラタント流体, } \quad \tau_{\mathrm{y}} \neq 0, \mathrm{n}=1: \text { ビンガム流体 }
\end{aligned}
$$

ここに, $\tau$ : せん断応力, $\tau_{\mathrm{y}}$ : 降伏值（降伏せん断応力）， $\mu_{\mathrm{ap} \mathrm{p}}$ :見かけの粘性， D (=du/dy) : ずり速度， $\mathrm{n}:$ : レオロジー定数

W. 0stwaldは実験により,これらの懸濁液の流動曲線（せん断 応力〜ずり速度関係)は図一 1 のように, ずり速度の小さな領域 と大きな領域でニュートン流体の挙動を示し,その間では擬塑性 流体からダイラタント流体に変化することを示した（図一1の ような曲線を0stwald曲線と言う.）0stwaldは, 図ー1のような 曲線が描かれるのは, 液体内にあって変形を妨げているある種の 構造が，流動とともに破壊されるためであるとした，つまり、ず り速度が小さいとき構造は破壊されず，その構造に対する粘度

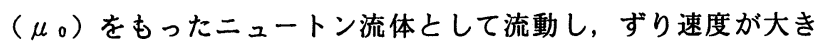
いときは構造が全く破壊された状態となり,その構造に対する粘 度 $(\mu \infty)$ をむったニュートン流体として流動する．その間では

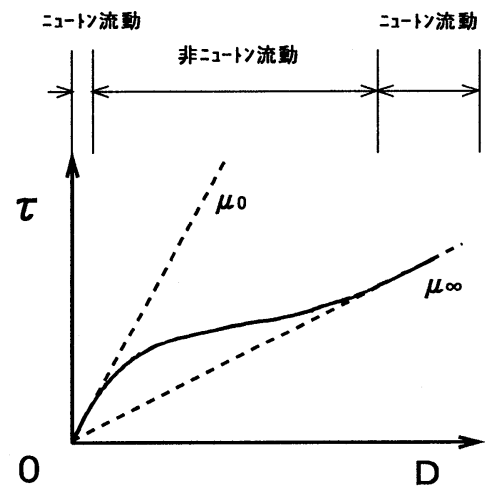

図- 1 0stwald曲線 流動によって構造が破壊されつつ,それに応じた粘度をもった流 体として流動する．このような意味で, 0stwaldは図－1のようにずり速度とともに変化する粘性を構造粘性 と呼んだ. Ostwald曲線を示す流体に対するレオロジー方程式が,多〈の研究者により提示されている. ${ }^{1) ， 22 ~}$

\section{2 流動曲線}

回転粘度計を用いて求めたカオリナイトの流動曲線を，4 種の含水比Wについて図 -2 に示す.この図より, 含水比が 比較的小さい場合は, 0stwald曲線のようにずり速度の小さな 領域とずり速度の大きな領域で粘度が一定の流動を示し，そ の間の領域ではずり速度とともに粘度が変化していくのがわ かる. また，0stwald曲線にはみられない降伏值 $\tau$ y が存在す る.そこで，M. Reinerの式 ${ }^{3)}$ を参考に，レオロジー方程式を 次式のように表す.

$$
\tau=\tau_{,}+\left\{\mu_{\infty}+\left(\mu_{0}-\mu_{\infty}\right) \mathrm{e}^{-\frac{1}{x} \mathrm{D}}\right\} \mathrm{D}
$$

ここに, $\chi:$ 構造安定係数

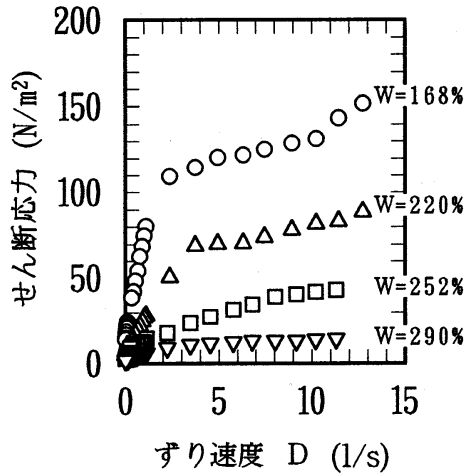

図一 2 カオリナイトの流動曲線

(2)式中のパラメー夕, $\tau_{y}, \mu_{0}, \mu_{\infty}, \chi$ は含水比によっ

て各々変化する. 実験によってこれらパラメータと含水比Wの関係を求めた結果が図 $-3 \sim 6$ である. 図中 の回帰直線より両者の関係は次のように定式化できる. 

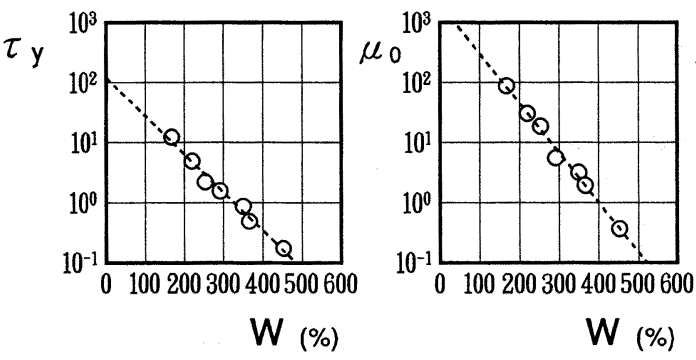

$$
\begin{aligned}
& \text { 図-3 } \tau_{y} \sim W \\
& \text { 図 }-4 \quad \mu_{0} \sim W \\
& \tau_{\mathrm{y}}=\exp (4.79-0.0147 \times \mathrm{W}) \\
& \left(\mathrm{N} / \mathrm{m}^{2}\right) \\
& \mu_{0}=\exp (7.62-0.0191 \times \mathrm{W}) \\
& \mu_{\infty}=\exp (5.25-0.0166 \times \mathrm{W}) \\
& \chi=\exp \left(0.919+6.71 * 10^{-4} \times \mathrm{W}\right)
\end{aligned}
$$

上式の関係を用いて得られる（2)式のレオロジー方程式と 回転粘度計による流動曲線を比較したものが図 - 7 であり， 両者はずり速度の全ての範囲で良好な一致を示している.

\section{3. 流送実験}

一方向流れ場における底泥の流動を調べるために, 図 -8 に示す実験水路を用いて流送実験を行った. 底泥材料として カオリナイトを用い，あらかじめ均一な含水比に調節してお いた底泥を水路凹部に敷き通水する. 通水による含水比変化, 含水比の鉛直分布，底泥流速分布を測定した。なお，底泥流 速の測定にはサーマル式微流速計を用いた.

\section{1 含水比変化について}

底泥を静水中に 15 分間放置した後，および15分間通水した 後, それぞれの場合につき各深さごとに底泥をサンプリング し, 含水比の銛直分布を求めた結果が図 - 9 である（初期含 水比 $\left.\mathrm{W}_{0}=554 \%\right)$. 静水中に放置した場合でもごく表層付近で 含水比は上昇するが, 通水によってさらに含水比が上昇する のがわかる. 含水比の上昇は表層から $1 \sim 2 \mathrm{~cm}$ での範囲でお こり, 表層に近いほど含水比の上昇量む大きい分布形となる。 それより樑い層では, 初期含水比とほとんど 変わらないか, もしくは粘土粒子の沈降によって含水比は若干減少する.

\section{2 底泥流速について}

底泥流速分布を図一10に示す. 底泥流速は表層付近で大きく，すぐ下層で急激に減少し，深さとともにさ らに減少してある深さ以下では底泥流速はゼロになる，そこで，泥表面から底泥流速がゼロになる深さまで の距離を流動化層厚と呼ぶことにする.

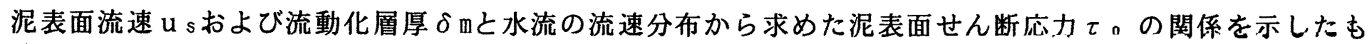
のが図-11および図-12である，両図とも同一含水比のプロットは左下から右上に並び，泥表面に作用する せん断応力が大きいほど泥表面流速，流動化層厚が大きくなることを示している．また，含水比が大きいほ ど泥表面流速, 流動化層厚が大きくなる傾向も明らかである.

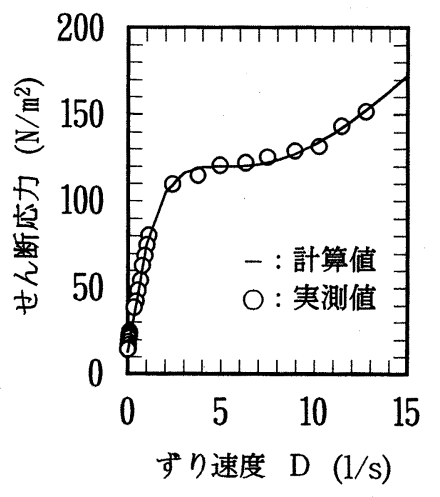

図ー7 流動曲線のモテル化

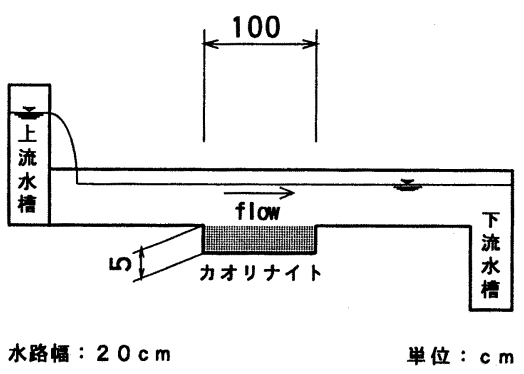

図-8 実験水路模式図 

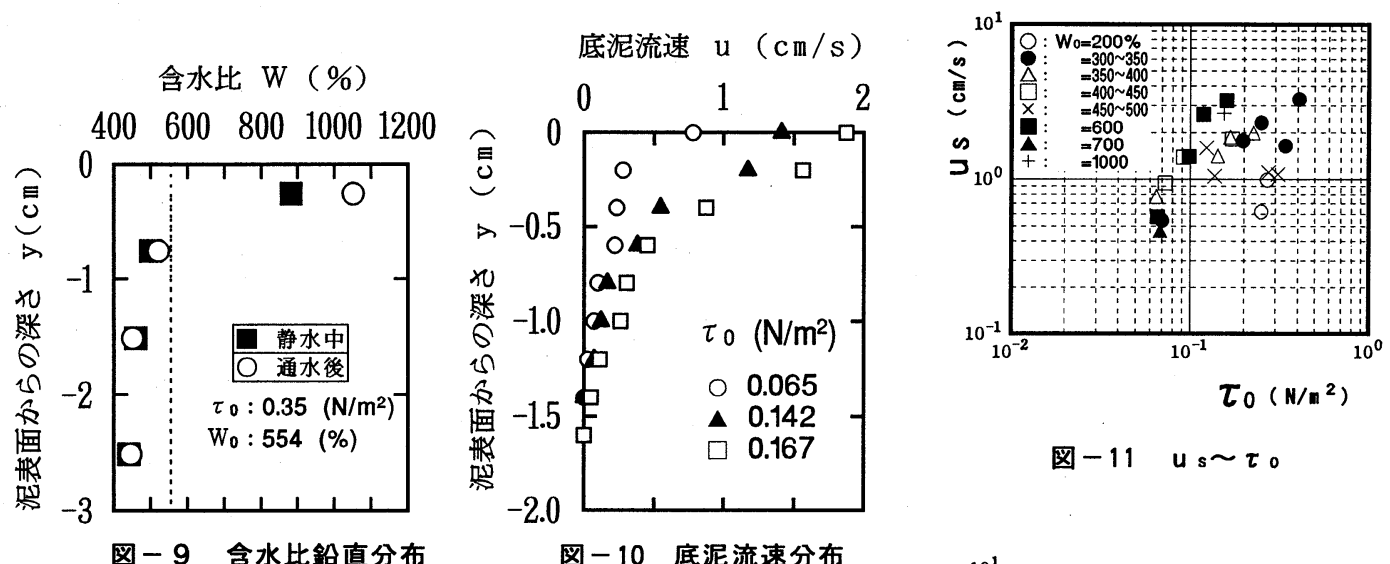

図 9 含水比鉛直分布

図-10 底泥流速分布

\section{4. 構造粘性を考慮した流動モテル}

（2）式のレオロジー方程式を用いて，一方向流れにより底泥表面 にせん断力が作用するときの底泥の流動をシミュレートする．流れ の基礎方程式は次のように構成する．底泥の流れは二次元定常流れ であるとし，圧力勾配は存在しないとする．また，底泥のレオロジ 一方程式が(2)式の形で与えられるのは, 底泥粒子で構成される構造 が破壊されるためであると考え，この構造破壊に伴って流水抵抗が 作用するものとする.

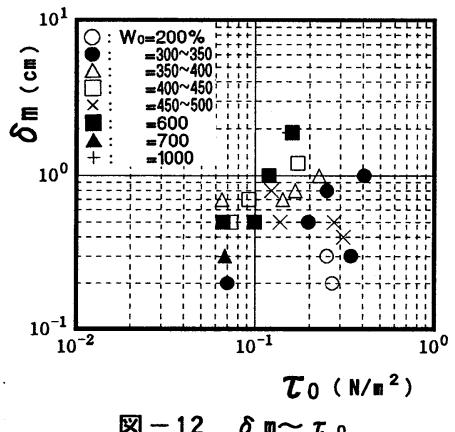

\section{1 基硉方程式}

上記の仮定のもとに，底泥の運動方程式を次式のように表す.

$$
\frac{\mathrm{d} \tau}{\mathrm{d} \mathrm{y}}-\rho \mathrm{F}_{\mathrm{x}}=0
$$

$\mathrm{F} \times$ は, 底泥構造の破壊によって粒子間結合に変化が生じ, その結合状態に対応する底泥粒子と周囲水の攪

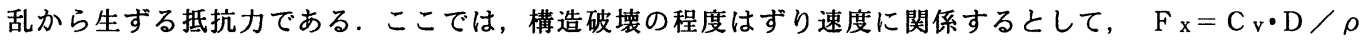
( $\mathrm{C}_{\mathrm{v}}$ : 抵抗係数) とする.

(2)式のレオロジー方程式を(3)式に代入すれば次式を得る.

$$
\begin{gathered}
\frac{\mathrm{d} \tau_{\mathrm{y}}}{\mathrm{d} \mathrm{y}}+\frac{\mathrm{d} \mu_{\infty}}{\mathrm{d} y} \mathrm{D}+\frac{\mathrm{d} \mu_{0}}{\mathrm{~d} y} \mathrm{e}^{-\frac{1}{x} \mathrm{D}} \mathrm{D}-\frac{\mathrm{d} \mu_{\infty}}{\mathrm{d} y} \mathrm{e}^{-\frac{1}{x} \mathrm{D}} \mathrm{D}-\frac{\mathrm{d}}{\mathrm{d} y}\left(\frac{1}{\chi}\right)\left(\mu_{0}-\mu_{\infty}\right) \mathrm{e}^{-\frac{1}{x} \mathrm{D}} \mathrm{D}^{2} \\
-\left(\mu_{0}-\mu_{\infty}\right) \frac{1}{\chi} \mathrm{e}^{-\frac{1}{x} \mathrm{D}} \mathrm{D} \frac{\mathrm{d} \mathrm{D}}{\mathrm{d} y}+\mu_{\infty} \frac{\mathrm{d} \mathrm{D}}{\mathrm{d} y}+\left(\mu_{0}-\mu_{\infty}\right) \mathrm{e}^{-\frac{1}{x} \mathrm{D}}-\mathrm{C}_{\mathrm{v}} \mathrm{D}=0
\end{gathered}
$$

各パラメータを, 前述の実験結果より含水比 Wの関数として $\tau_{y}=\exp \left(a_{1}+b_{1} \cdot W\right), \mu_{0}=\exp \left(a_{2}+b_{2} \cdot W\right)$, $\mu_{\infty}=\exp \left(\mathrm{a}_{3}+\mathrm{b}_{3} \cdot \mathrm{W}\right), \chi=\exp \left(\mathrm{a}_{4}+\mathrm{b}_{4} \cdot \mathrm{W}\right)$ と与えれば, 次式となる.

$$
\begin{gathered}
\mathrm{b}_{1} \frac{\mathrm{dW}}{\mathrm{dy}} \tau_{\mathrm{y}}+\mathrm{b}_{2} \frac{\mathrm{dW}}{\mathrm{d} y} \mu_{\infty} \mathrm{D}+\mathrm{b}_{3} \frac{\mathrm{dW}}{\mathrm{d} y} \mu_{0} \mathrm{e}^{-\frac{1}{x} \mathrm{D}} \mathrm{D}-\mathrm{b}_{2} \frac{\mathrm{d} \mathrm{D}}{\mathrm{d} y} \mu_{\infty} \mathrm{e}^{-\frac{1}{x} \mathrm{D}} \mathrm{D} \\
+\left(\mu_{0}-\mu_{\infty}\right) \mathrm{b}_{4} \frac{\mathrm{dW}}{\mathrm{d} y} \frac{1}{\chi} \mathrm{e}^{-\frac{1}{x} \mathrm{D}} \mathrm{D}^{2}-\left(\mu_{0}-\mu_{\infty}\right) \frac{1}{\chi} \mathrm{e}^{-\frac{1}{x} \mathrm{D}} \frac{\mathrm{d} \mathrm{D}}{\mathrm{d} y} \\
+\mu_{\infty} \frac{\mathrm{d} \mathrm{D}}{\mathrm{d} y}+\left(\mu_{0}-\mu_{\infty}\right) \mathrm{e}^{-\frac{1}{x} \mathrm{D}} \frac{\mathrm{d} \mathrm{D}}{\mathrm{d} y}-\mathrm{C}_{\mathrm{v}} \mathrm{D}=0
\end{gathered}
$$


（5）式を解けば，ずり速度の鈶直分布 $\mathrm{D}(\mathrm{y})$ が得られる. D ( y )が 求まれば, 適当な境界条件のもとに(6)式を解いて底泥流速分布が 求まる.

$$
\frac{\mathrm{d} u}{\mathrm{~d} y}=D(\mathrm{y})
$$

\section{2 計算方法}

（1）含水比の鉛直分布 $\mathrm{W}(\mathrm{y})$ を仮定する.

（2） $\mathrm{y}=0$ (底泥表面）に，せん断応力 $\tau$ 。が作用するという境界条 件のもとに(2)式を解いて，y=0におけるずり速度 $\mathrm{D}$ 。を求める. (3) $\mathrm{y}=0$ で D = D。の境界条件のむとに(5)式を解いて $\mathrm{D}(\mathrm{y})$ を求め る. $\mathrm{D}(\mathrm{y}), \mathrm{W}(\mathrm{y})$ からせん断応力の鉿直分布 $\tau(\mathrm{y})$ および降伏值 の鉛直分布 $\tau_{\mathrm{y}}(\mathrm{y})$ が求められる. $\tau>\tau_{\mathrm{y}}$ のとき底泥は流動化す ると考えられるから, 各深さにおいて $\tau$ と ${ }_{\mathrm{y}}$ の大小を比較して 流動化層厚 $\delta \mathrm{m}$ 求める.

(4) $\mathrm{y}=\delta \mathrm{m} て ゙ \mathrm{u}=0$ の境界条件のもとに(6)式を解き底泥流速分布 $\mathrm{u}(\mathrm{y})$ を求める.

上述の (3)における計算は, 4 次のRunge-Kutta法で行った.

\section{3 計算結果}

上述の方法で計算した底泥流速分布は, 抵抗係数 $\mathrm{C} \mathrm{v}$ や含水比の 鉛直分布 $\mathrm{W}(\mathrm{y})$ の違いによって大きな相違を示した。ここでは主に 抵抗係数 $\mathrm{C}_{\mathrm{v}}$ の影響について考察する. また，レオロジー方程式に おける構造粘性の考虑が, 流速分布にどのようにあらわれるか示す.

(1) $C_{\mathrm{v}}$ の影響について

(i) 抵抗係数 $\mathrm{C}_{\mathrm{v}}=0$ のとき

$\mathrm{C}_{\mathrm{v}}=0$ とすれば, 流動化層厚および流速分布形は含水比の鉛直分 布形W(y)のみによって決定される．W（y）によって定まる降伏值 の最大值より小さいせん断応力が作用する場合 はある深さで流動が止まるが, 降伏値の最大値 以上のせん断応力が作用する場合は底泥の全層 が流動する. 実際にはこのように大きなせん断 応力が作用しても，ある深さより下の底泥は流 動することはない。

$$
\text { (ii) } \mathrm{C}_{\mathrm{v}}=\text { 定数のとき }
$$

$\mathrm{C}_{\mathrm{v}}=$ 定数とした場合, 図一13および図-15(a) の $\delta \mathrm{m}$ に示すように,含水比の大きい場合の方が 流動化首厚は小さくなることがおこり，含水比 の増加とともに流動化層厚が増加するという実 験結果を再現しない， $\mathrm{C}_{\mathrm{v}}=$ 定数としたことによ って抵抗力 $\mathrm{F} \times$ がずり速度 Dのみによって決定 されるため，相対的にずり速度が大きくなる高 含水比の場合に大きな抵抗力が働き流動化層厚 は小さくなると考えられる.

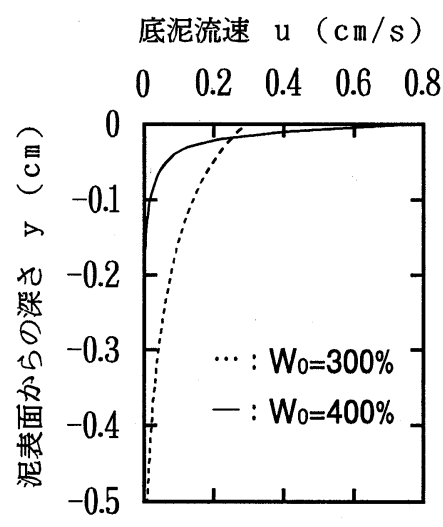

図 -13 底泥流速分布 $\left(C_{\mathrm{v}}=\right.$ 定数 $)$ $\begin{array}{lllll}0 & 0.2 & 0.4 & 0.6 & 0.8\end{array}$

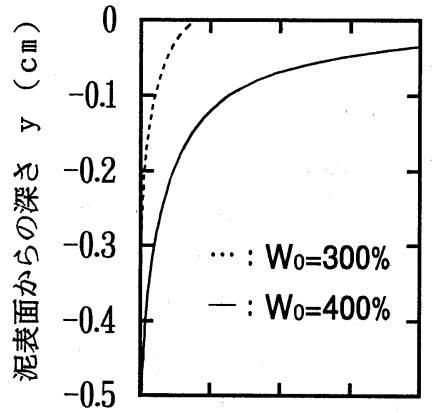

図-14 底泥流速分布 $\left(C_{\mathrm{v}}=\right.$ 関数 $)$

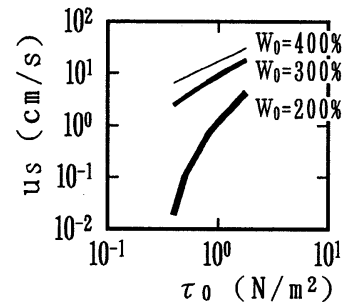

$\tau_{0}\left(\mathrm{~N} / \mathrm{m}^{2}\right)$

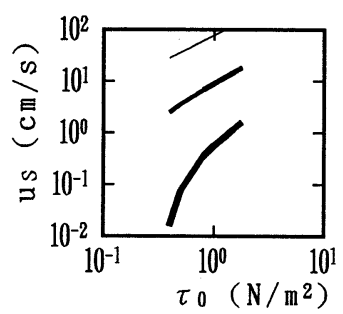

(a)
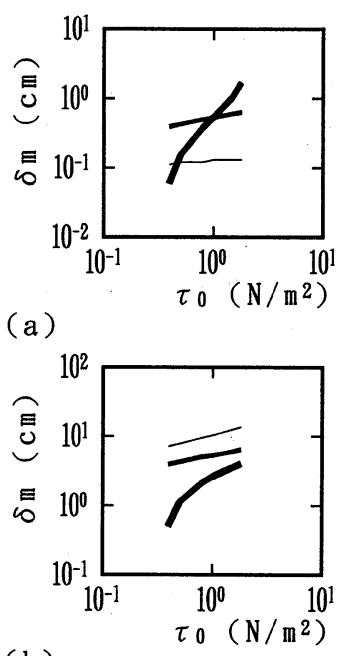

(b)

図-15 us $\tau$ 。， $\delta \mathrm{m} \sim \tau$ 。（計算） 
（iii） C vを含水比の関数とするとき

含水比の增加とともに $\mathrm{C}_{\mathrm{v}}$ の值が減少するものとする. 他のパラメータと同様に $\mathrm{C}_{\mathrm{v}}=\exp (\mathrm{a}+\mathrm{b} \times \mathrm{W})$ とす れば, 図一14および図-15(b)に示すように, 含水比およびせん断応力とともに us, $\delta$ 㽖增加するという実 験結果の傾向が再現される.

(2)構造粘性の導入の効果

上述のように，構造粘性を導入して(2) 式を用いて底泥流速分布 を求めた，すなわち，ずり速度による粘度の変化を考慮に入れてい る.一方, 構造粘性を考虑せず，ずり速度によって粘度が変化しな いビンガム流体として底泥流速分布を計算し, 両者の分布形を比較 すると図ー16のようである．ビンガム流体とした場合は，粘度（一 定値）をこの図のように 2 通りの值にとっても，底泥流速分布の特 徵である底泥表面付近の急激な速度增加を再現できないが, 構造粘 性を導入した場合には実測の流速分布に近い分布形になる.

このように, 流動曲線をもとに構造粘性を仮定した結果, 底泥の 流速分布形状が良好に再現できることから, 流れによる底泥の流動 過程においても粘土粒子集合体の構造破壊およびそれに伴う粘度の 隇少という現象が生じていると推測される.

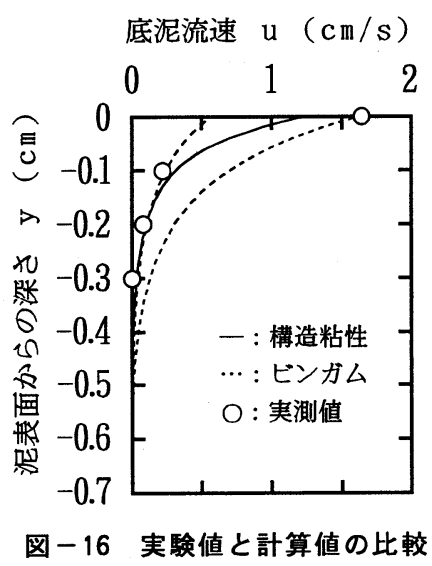

\section{5.まとめ}

底泥を高濃度懸濁液と考え, 粘度が含水比だけでなく流動の状態によっても変化するという物性を考虑に 入れて，底泥の流動モデルに関する検討を行った．得られた結果をまとめると以下のようである．

（1）構造粘性を導入したレオロジ一方程式が，底泥(カオリナイト)の流動曲線を良好に再現する結果を得た。 また，このレオロジー方程式のパラメータは含水比の関数として表された.

（2）実験により，一方向流れ場における底泥の流動現象を測定し, 泥表面流速および流動化層厚が含水比お よび底泥表面に作用するせん断力とともに増加することを明らかにした.

（3）構造粘性を考虑した流動モデル用いて底泥流速分布を計算した. 計算結果は, 従来のモデルでは再現 できなかった底泥流速分布形の特徴を再現することができた。

今後, さらに詳しい含水比の鉊直分布の測定や，底泥材料をかえた場合の流送現象およびレオロジー特性 の測定を行わなければならない，また，底泥の運動方程式に導入した抵抗力 $\mathrm{F} \times \mathrm{x}$ の定式化についてさらに検討 する必要がある.

\section{卷考文献}

1）後藤廉平・平井西夫・花井哲也：レオロジーとその応用, 共立出版, 1962.

2) Pierre Y. Julien and Yongqiang Lan : Rheology of Hyperconcentrations, Journal of Hydraulic Engineering, Vol.117, No. 3, pp. 346 353, 1991.

3）山田嘉明・柳澤延房：改訂レオロジーの基礎理論, コロナ社, 1976. 